\title{
建築形状の形容詞による言語的操作の計算論的モデル A COMPUTATIONAL MODEL OF LINGUISTIC INSTRUCTIONS ON ARCHITECTURAL FORM WITH ADJECTIVES
}

\author{
青木義 次*, 稲毛 誠** \\ Yoshitsugu AOKI and Makoto INAGE
}

\begin{abstract}
In a process of architectural design, the role of the language use is important. In order to make the function of language in design process clear, we construct a computational model of linguistic instructions to modify the architectural forms. In the model, the words as linguistic instructions and forms are expressed as vectors in a semantic space. The relation of these vectors is determined by experiments of word-association to the graphical presentation of forms. The graphical presentation of each form is determined by design variables. The mapping from the vectors to design variables is estimated by neural network model.
\end{abstract}

keywords: Linguistic instructions, Semantic space, Architectural design, Neural network model, Computational model 言語的操作，連想イメージ空間，建築設計，ニューラルネットワークモデル，計算論的モデル

1 はじめに

建築設計では，図面を描くことを強調するあまり，設計プロセス での言語が果している役割を過少に評価しがちである。たとえば, 設 計の開始時点で, 設計者が「あたたかみのある空間にしたい」と作 品の目指すべき方向を扔ぼろげに把握しているとき，そこには具体 的な建筑の形が把握されているとは限らない。むしろ，『あたたか み』という自由度の高い可能性を帯びたイメージが，この「あたた かみ」という言語もしくは概念によって設計者の身体の中にアン カーされたというのが適切だろう。さらに, 一人で設計するのでは なく，多くのスタッフとの協力によって建築設計がなされる場合で あれば，各自のイメージは言語を介して伝達され，言語の役割が一 層重要であることは論をまたない。

本研究では上記の視点に立ち, 計画・設計における言語の果たす 役割と機能の解明を最終的な研究目標と寸る。しかし，ややもする と言語にとらわれるあまり言葉の遊歔に宿る可能性があり,これを 回避するため, 当面の課題として, 設計プロセスでの言語使用を具 体的なモデルとして定式化し，同時にそうしたモデルが設計支援の 道具となりうる可能性を追求する。

\section{2 既往研究と本研究の伜組}

計画や設計を言語との関係として把握したものとしては，渡辺の 一連の研究 ${ }^{1-2)}$ に遡ることができ, 計画内容を妥当性が問われるべき 論理的言語表現とみなしている。この枠組みを継承したものとして, 近年の青木らの研究 ${ }^{3-4)}$ もある。しかし, 計画や設計を論理的対象と 見る以前に, 記号表現の作成過程であるという視点もありうる。青
木 ${ }^{5-8)}$ は, 住民や施主の言語表現を受け入れてプランという記号表現 を変化させてゆくプロセスを計画過程と呼び, チョムスキーの生成 文法理論を活用して, 計画の理論自体が不完全とならざるを得ない ことを示している。類似した枠組みとして，設計行為を，われわれ を取り巻く世界の状態を推移させる記述の作成過程とみる藤井らの 研究7-8)があり；一層具体的な展開がなされている。またここれ.らと は別に建築で使用されている用語の意味が，その使用形態から確定 できるという青木の研究量がある。

本研究では、これら既往の研究の一般論的アプローチから離れて， 特殊なケースを想定し，その状況を再現する計算可能なモデルを具 体的に作成し，言語の持つ機能を明確化することを試みる。このよ うな研究方法は認知科学の分野で成功をおさめた研究方法であり, モデルが唯一性を有していることを保証することは困難であるもの の研究対象の理解を哚めるのに有効であり, 具体的なモデルの改良, 修正も容易である。

ここで想定した状況とは以下のような設計プロセスでの 1 場面で ある。ある建築家が，スタッフと設計案を前にして打合せをしてお り，たとえば「もっと，軽やかな感じにしたい」と述べ，スタッフ が，この言語表現をもとに設計案を描きなおす場面である。設計案 では具体的にさまざまな寸法が決まっており，これに対して「軽や か」という言語表現はあまりにも抽象的と言わざるを得ないが、こ うした状況で，スタッフは設計案の適切な修正をしている。われわ れの課題は，なぜ，このような単純な言語表現で複雑な設計修正が 可能なのか，どのような仕措けで，このようなことが可能となるの かという疑問に答えることである。
* 東京工業大学理工学研究科建築学尃攻 教授. 工博

** 東京工業大学理工学研究科建築学尃攻 大学院生
Prof., Dept. of Architecture, Tokyo Institute of Technology, Dr. Eng. Graduate Student, Dept. of Architecture, Tokyo Institute of Technology 
そこで，研究としては，ある程度複雑な設計案に对して，上記の ような簡単な言語表現を与えて, 設計案を修正する具体的な計算論 的モデルを実際に構築して，人間が䚿計プロセスで言語を活用する 状況の意味の一端を明らかにする。

設計案が简単すぎては現実性を欠くと考えられるので,ここでは， 寸法等の情報量が多い設計対象として 3 次元的曲面の屋根形状とす る。実際の設計では施主の要望など複雑な言語表現があるが, 本研 究では建築形状に関するものに限定し，さらに論理的に定義しにく い感情的な言語表現として形容詞のみとする。

\section{3 基本的枠組み}

研究に先立ち基本的な考え方を整理しておきたい。

まず，形状の幾何学的性質について検討する。たとえば放物線を 2 次方程式として表すこともグラフなどの視覚像で表すこともでき る。このように, 一般に幾何学的形状や図形は, 複数の記述方式が ある。また，その記述形式が異なっていても，同一の幾何学的形状 を表していると述べることがある。そこで, 本研究では, 形状の幾 何学的性質を決定づける記述方式には数理的に便利なスプライン関 数を用い，人間への提示方式としてはディスプレイ画面の視覚像を 採用することにする。

一方，形状に対して，言葉を用いて形容することができる。この 事実は，形状と形容する言葉とが，ある機構を通じて関連している ということでありここの関連機構を表す数理的モデルを想定するこ とが有意義であることを示唆している。実際, 建築計画研究の中で 多用されているSD法では, 空間と形容詞との関連を表す機構の数 理モデルとして, 意味空間を構成し, その解釈から多くの知見を得 ている。しかし，このようなモデルは，実在しているわけではなく， また唯一のものでもなく, 仮説的なモデルであり, 観測事実との整 合性と有用性から導入されていると考えるべきであろう。本研究で も, 同様のアプローチを探用し, 形状と形容詞との関係を表す機構 として，連想イメージ空間というモデルを導入する。

\section{4 設計対象とデザイン变数空間}

一般に, 幾何学的形状は, その形状が満足すべき関数形と関数の パラメー夕を指定することで定まる。そこで, 現在, 複雑な曲面形 状の設計に活用されているスプライン関数を利用する。この関数で は, 曲面が通過する点の座標を指定することでスプライン関数のパ ラメータが完全に決まるので, 通過点座標の組を与えることが曲面 を指定したとみなせる。そこで, 通過点座標の組を「デザイン変数』 と呼ぶ。以下の検討では, 図 1 に示すように, X方向, $\mathrm{Y}$ 方向にそ れぞれ等間隔で指定基準点を 5 個とり， $5 \times 5=25$ の点の高さ，つ
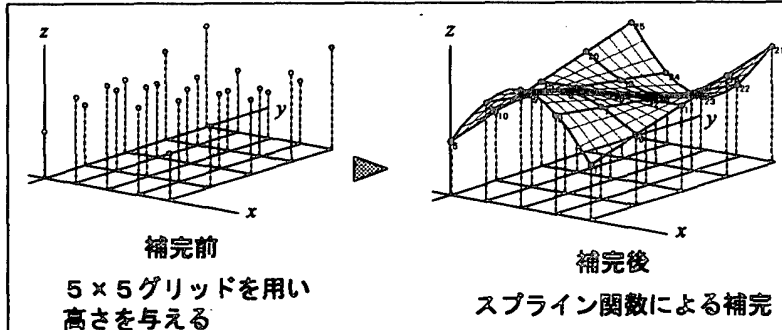

図1 スプライン関数による曲面表現
まり Z座標を指定することで，曲面が定まる。したがって，25次元 の空間のひとつの点がひとつの曲面形状を表す。この空間をデザイ ン変数空間と呼ぶ。また, 形枤 $F_{j}$ は, 25 個の要素からなる以下のべ クトルで表し，形状 $F_{j}$ のデザ!ン変数表示と呼ぶ。

$$
\mathrm{y}_{j}=\left(y_{j 1}, y_{j 2}, \cdots, y_{j 25}\right)
$$

以上は, 前述の形状の幾何学的記述としてデザイン変数表示を選 択したことを意味している。

\section{5 対象と言語衰現の関係モデル}

\section{5-1 尰想イメージ空間のモデル注1}

対象と言語表現との関係を考える上で，前述のオズグッドの SD 法の考え方が参考になる。そこでは，各対象の意味ないしは認識内 容が意味空間に布置できるという仮定がなされてる。つまり，各対 象に対する形容詞対についての評定デー夕をもとに，そのデータと もっとも整合的な距離空間を仮定して, 各形容詞対および各对象を この空間に埋め込む。この媒介的に導入された意味空間の存在仮定 は立証不能であるが, 意味空間の解釈を通じての知見は現実的に有 用とみなされている。本研究でも同様に, 対象と言語との関係づけ として, 媒介的な距離空間を仮定する。ただし, SD法では形容詞対 という形で，ある形容詞とある形容詞が意味空間上で逆方向のベク トルとなることを最初から想定しているが，いくつかの形容詞につ いては，この想定は自明ではない。たとえば「あでやか」の対とし て「地味」をとるとしても，「地味」の対として「はなやか」があ りうる。このとき「あでやか」と「はなやか」には微妙な差異があ る。設計者が言語を用いて建築の形状を表現するときこうした微 妙な差異は無視しえない。そこで, 以下のような方法で意味空間の 替わりとなる連想イメージ空間を構成してゆくことにする。

前提となるのは，建築の形状を見たとき，たとえば「軽快な感じ がする」というように言葉を連想しうるという事実である。また， とつの対象に対して, 複数の言葉も連想しうるし, さらに, 連想さ れやすさの程度に違いもある。つまり,ある言葉は直ぐに浮かぶが， 「言われてみるとそういう感じもする」という程度の言葉もある。以 下の定式化では，N個の形状 $F_{j}(j=1 \sim \mathrm{N})$ があり，M個の言葉（実 際には形容詞) $W_{i}(i=1 \sim \mathrm{M})$ があるとして, 形状 $F_{j}$ に対して言葉 $W_{i}$ の連想の程度を $p_{i j}$ とする。データを得る段階ではこの $p_{i j}$ は連想 の頻度として計測する。以下では, 連想の程度 $p_{i j}$ がデータから既知 となっているとして, 連想イメージ空間の構成法を述べる。各形状 $F_{j}$ と言葉 $W_{i}$ は, この空間でのベクトル $\mathrm{x}_{j}$ および $a_{i}$ に対応するような 距離空間を考える。すなわち，

$$
\begin{aligned}
& \mathrm{x}_{j}=\left(x_{j 1}, x_{j 2}, \cdots, x_{j \mathrm{~K}}\right) \\
& \mathrm{a}_{i}=\left(a_{i 1}, a_{i 2}, \cdots, a_{i \mathrm{~K}}\right)
\end{aligned}
$$

となるK次元距離空間を想定する。ベクトル $\mathrm{x}_{j}$ を形状 $F_{j}$ の連想イメージ空間表記と呼び, $\mathbb{a}_{i}$ を言葉 $W_{i}$ の連想イメージ空間表記と呼ぶ。た だし，この空間の次元 Kは未知である。このふたつのべクトルは, 観 測データである連想の程度 $p_{i j}$ をよく説明できる関係になっていなけ ればならない。ある形状がある言葉を連想するとしたとき，それら の形状と言葉とに強い関係があれば, 連想の程度 $p_{i j}$ むきくなると 考えられる。一方，2つのベクトルの類似性は，それらの内積で表 
現できるので, ベクトル $\mathbf{x}_{i}$ および $\mathbf{a}_{i}$ の内積が連想の程度 $p_{i j}$ に比例す るいう関係がもっとも率直である。これを数学的に記述すれば, 2 種 のべクトル $\mathbf{x}_{j}$ および $\mathbf{a}_{i}$ の大きさが後に述べるように基準化されてい るとき，

$$
p_{i j}=\sum_{k=1}^{\mathrm{K}} a_{i k} x_{j k}+e_{i j} \quad(i=1 \sim \mathrm{M}, j=1 \sim \mathrm{N}) \quad(5-3)
$$

となる。ここで, $e_{i j}$ はモデルとデータとの差すなわち誤差であり， この誤差が小さいほど望ましい。

以下, 未知変数 $\mathbf{x}_{j}$ および $\mathbf{a}_{i}$ を求めるため, $a_{i k}$ を $(i, k)$ 要素とする $\mathrm{M} \times \mathrm{K}$ 行列を $\mathbf{A}, x_{j k}$ を $(j, k)$ 要素とする $\mathrm{N} \times \mathrm{K}$ 行列を $\mathbf{X}$ とする。ま た, $p_{i j}$ を $(i, j)$ 要素とする $\mathrm{M} \times \mathrm{N}$ 行列を $\mathrm{P}, e_{i j}$ を $(i, j)$ 要素とする $\mathrm{M} \times \mathrm{N}$ 行列を $\mathbf{E}$ と書くと, 上記の関係式(5-1)は,

$$
\mathbf{P}=\mathbf{A} \mathbf{X}^{\mathrm{T}}+\mathbf{E}
$$

となる。さらに, 行列 $\mathbf{A}$ および行列 $\mathbf{X} の k$ 列を $\mathbf{a}_{(k)}, \mathbf{x}_{(k)}$ と表記して おく。連想イメージ空間の各次元 $k(k=1 \sim \mathrm{K})$ は独立であること, つ まり $\mathrm{K}$ 個の軸は直交しているという前提で,

$$
\begin{aligned}
& \mathbf{a}_{(k)}{ }^{\mathrm{T}} \mathbf{a}_{(k)}=c_{(k)} \mathbf{I}, \quad \mathbf{x}_{(k)}{ }^{\mathrm{T}} \mathbf{x}_{(k)}=d_{(k)} \mathbf{I} \\
& \text { ただし, } c_{(k)} \text { おうよび } d_{(k)} \text { は定数 }
\end{aligned}
$$

でなければならないが，以下ではべクトル $\mathbf{a}_{(k)}$ の長さを 1 , ベクトル $\mathbf{x}_{(k)}$ の長さを $\lambda_{(k)}$ の平方根と基準化すると,

$$
\mathbf{a}_{(k)}{ }^{\top} \cdot \mathbf{a}_{(k)}=\mathbf{I}, \quad \mathbf{x}_{(k)}{ }^{\mathrm{T}} \mathbf{x}_{(k)}=\lambda_{(k)} \mathbf{I}
$$

となる。

ここで，回㷌分析と同様に，自乗誤差の合計

$$
V=\sum_{i=1}^{M} \sum_{j=1}^{N}\left(e_{i j}\right)^{2}
$$

を最小化するように上記の未知変数 $\mathbf{x}_{j}$ および $\mathbf{a}_{i}$ を求める。この最小 化条件から，以下の式が容易に導ける。

$$
\begin{aligned}
& \mathbf{P} \mathbf{x}_{(k)}=\lambda_{(k)} \mathbf{a}_{(k)} \\
& \mathbf{P}^{\mathbf{T}} \mathbf{a}_{(k)}=\mathbf{x}_{(k)}
\end{aligned}
$$

この 2 式より，次の関係式を得る。

$$
\left(\mathbf{P} \mathbf{P}^{\mathrm{T}}-\lambda_{(k)} \mathbf{I}\right) \mathbf{a}_{(k)}=0
$$

この方程式は行列 PPT の固有值が $\lambda_{(k)}$ であり, 対応する固有べクトル が $\mathbf{a}_{(k)}$ であることを示している。したがって,この固有值問題を解い て $\mathrm{K}$ 組の $\mathbf{a}_{(k)}$ を得, これを(5-9) 式に代入して $\mathbf{x}_{(k)}$ を求めることがで きる。この際固有值 $\lambda_{(k)}$ が $k$ 次元目の説明力に対応している。

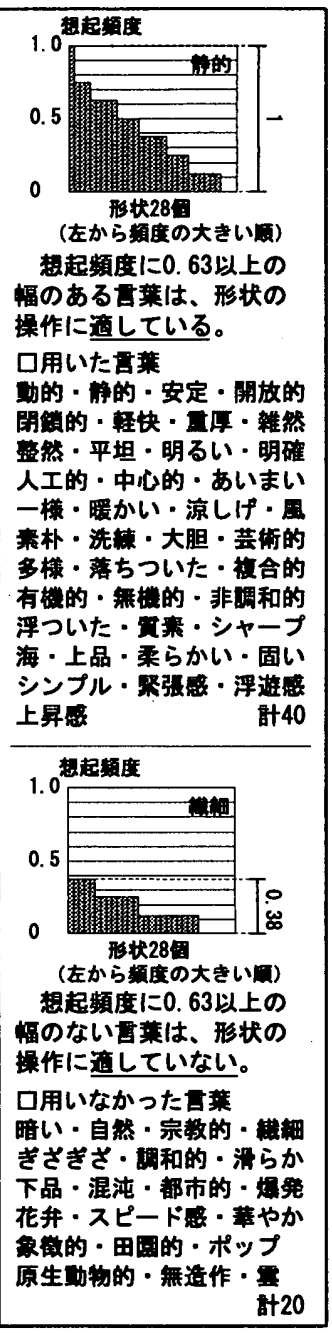

図 2 形容詞の選定

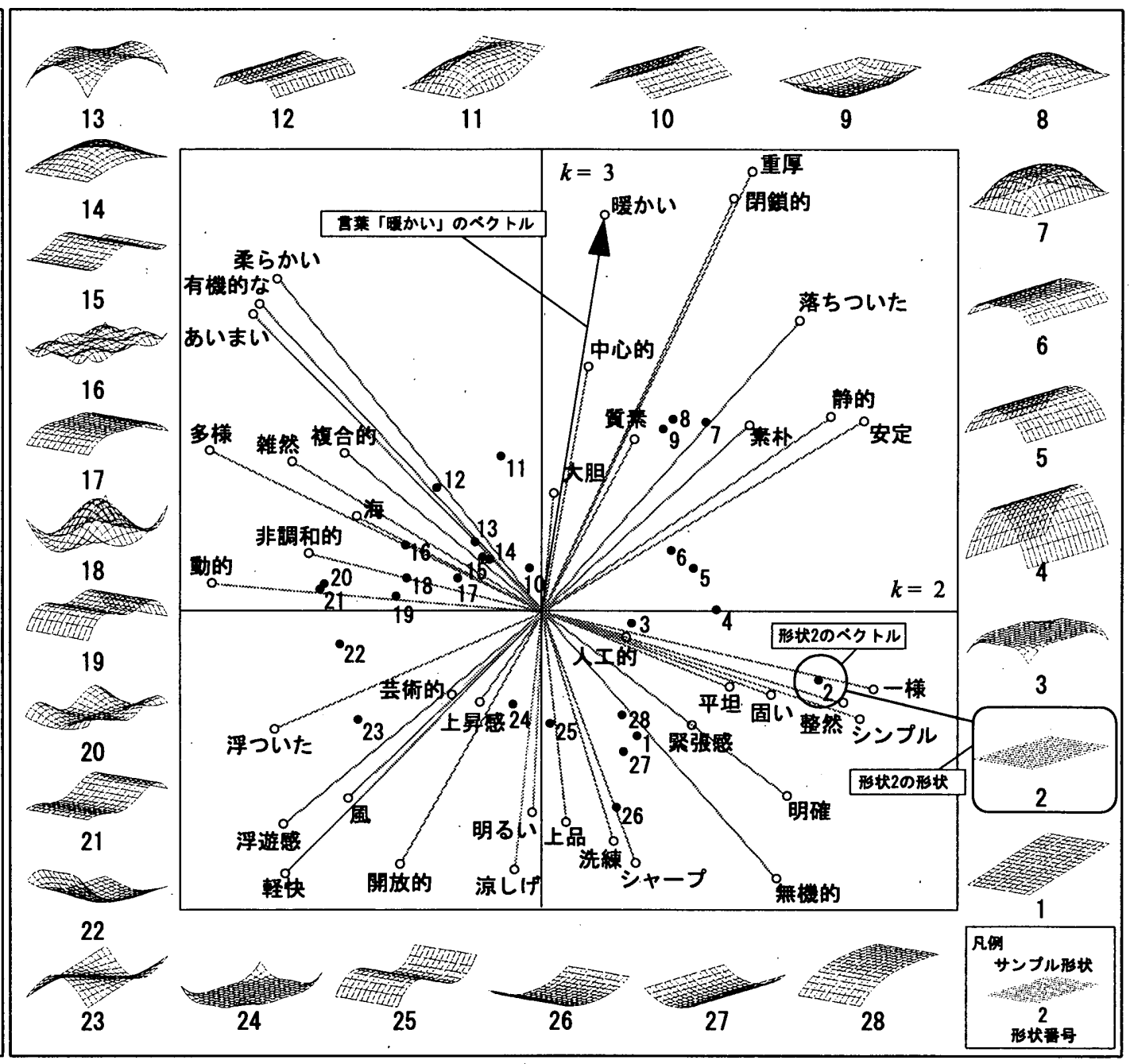

図 3 調査より求めた連想イメージ空間 


\section{5-2 㖶想イメージ空間の計測}

連想の程度 $p_{i j}$ を計測するため，被験者に形状を示し注22，形容詞の 想起頻度を調㚗した。当初 31 個のサンプル形状を準備し，事前に実 験者自身が自由連想法で60の形容詞をリストアップした。これをも とに，8人の被験者に対し，想起した形容詞にマークしてもらった。 各想起頻度を被験者数で除し, 連想の程度 $p_{i j}$ とした。

さらに，想起頻度がどの形状でも同程度である形容詞は形状の違 いを表現していないものとして, $p_{i j}$ の最大と最小の差が 0.63 以下の ものを除外し，結局 40 の形容詞に絞った（図2）。また，想起頻度の 極めて少ないサンプル形状3個を除外し，28のサンプル形状とした。

以上のデータから求めた結果の一部を示したものが図 3 である。 上記のモデルでは, $k=1$ の場合, 各形状, 各形容詞の想起頻度に比 例した量に相当するだけなので，実質的な意味の違いに注目すると $k=2$ がもっとも意味の違いを示す次元となる。

少ない被験者数ではあるが，原理的な確認のためには，各形状と 形容詞が適切に布置されていると考えられる注3》。

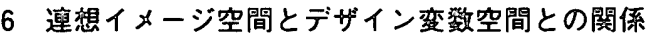

6-1 連想イメージ空間からデザイン变雚空間への写像

同一の曲面形状 $F_{j}$ が前述のように, デザイン空間表示の $\mathrm{y}_{j}$ と連想 イメージ空間表示の多を持つことになっているが,これらは同一の ものを別の表現で表したものであるから，本来，1対 1 の対応があ るはずである。そこで，連想イメージ空間のひとつの点

$$
\mathrm{s}=\left(x_{1}, x_{2}, \cdots, x_{\mathrm{K}}\right)
$$

とデザイン変数空間の点

$$
\mathrm{y}=\left(y_{1}, y_{2}, \cdots, y_{2 s}\right)
$$

との対応関係を求める必要がある。そこで，連想イメージ空間から デザイン変数空間への写像 $\phi$

$$
\mathrm{y}=\phi(\mathrm{s})
$$

を求める。この写像は, 同一な形状に関して,

$$
\mathrm{y}_{j}=\phi\left(\mathrm{s}_{j}\right) \quad j=1 \sim \mathrm{N}
$$

でなければならない。しかしこのような関数 $\phi$ は一般的に非線形

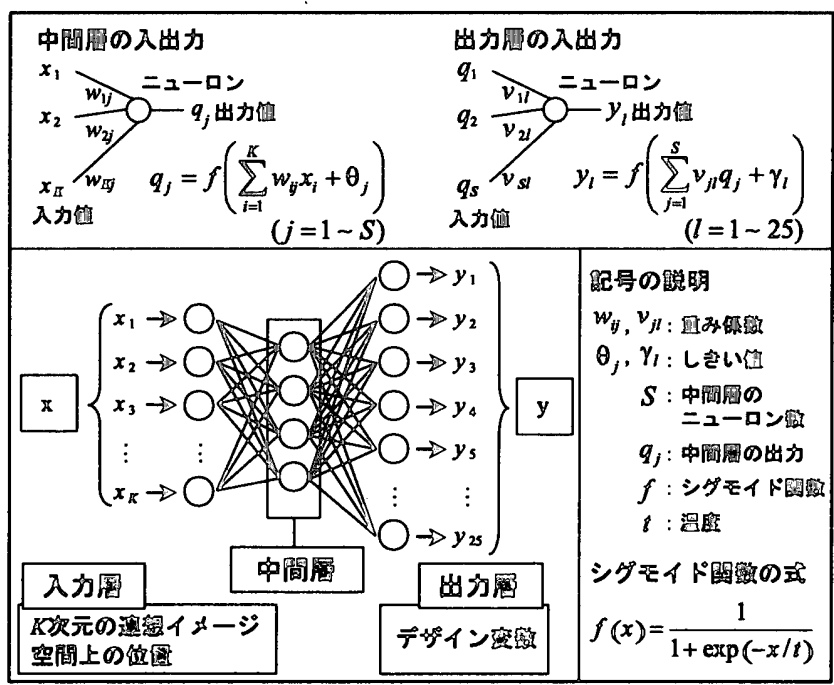

图 \& ニューラルネットワークモデル
であり，解析的に導出することは困難である。そこで，本研究では， ニューラルネットワークモデル注4)を活用して (6-4)式を近似的に 満足する関数 $\phi$ を求める。すなわち，図 4 に示すように，第 1 層の 入力層を $x_{1}, x_{2}, \cdots, x_{\mathrm{K}}$ とし, 第 3 層の出力層を $y_{1}, y_{2}, \cdots, y_{25}$ と する3層ニューラルネットワークモデルを用いて，(6-4)を教師デー 夕としてバックプロパゲーション法により学習させることで, (6-4) 式を近似的に成立させる関数 $\phi$ を求める。

6-2 ニューラルネットワークモデルの学習結果

前述の固有値問題の各固有值の大小は主成分分析と同㥞にその次 元 $k$ の説明力の大小を示す量なので, 固有值の累積自乗和が $95 \%$ 以 上となるように15次元まで探用した。すなわち，連想イメージ空間 の次元 $\mathrm{K}$ として $\mathrm{K}=15$ とした。また，図4の中間層の素子数として は試行錯誤の結果 15 とした。以上のもとでの学習回数ごとの自乗誤 差合計の減少の様子を示したものが図 5 である。100,000 回の繰り 返し学習の結果ほほ（6-4）を満足するようにできた。たとえば図 2 の No. 5 の形状についての連想イメージ空間の值 $\mathrm{x}_{5}$ を与えたときの $\mathrm{y}_{5}$ の推定值 $\phi\left(\mathrm{x}_{5}\right)$ を用いて描いた図を図 5 下段に示したが,これは $\mathrm{y}_{5}$ から描いた形状と視覚的には区別できないほど一致している。

\section{7 言檠による設計空の操作}

\section{7-1 言纂による修正と㖶想イメージ空間での移動}

前述のようにひとつの形状 $F$ は $\mathrm{K}$ 次元の連想イメージ空間の点 $\mathrm{x}$

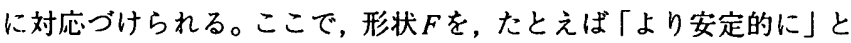
いう言葉で修正する状況を考える。

'連想イメージ空間では，各形容詞 $\mathbb{W}_{i}$ は $\mathrm{K}$ 次元のベクトル されていたので, ベクトル $\mathrm{x}$ の位置から, ベクトル $a_{i}$ の方向に移動 すれば，いっそう形容詞 $\mathbb{W}$ の連想の程度が強くなる。この事実を踏

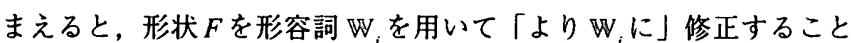
は, 形状 $F$ の連想イメージ空間の点

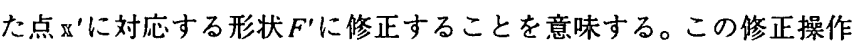
は，以下のようなべクトルの和で表現できる。

$$
\mathrm{x}^{\prime}=\mathrm{s}+\delta \mathrm{a}_{i}
$$

ここに $\delta$ は 1 回の修正の程度を表す正の微小定数である注5)。上記は 「より安定的に」というように形容詞の連想の程度を強めることを考

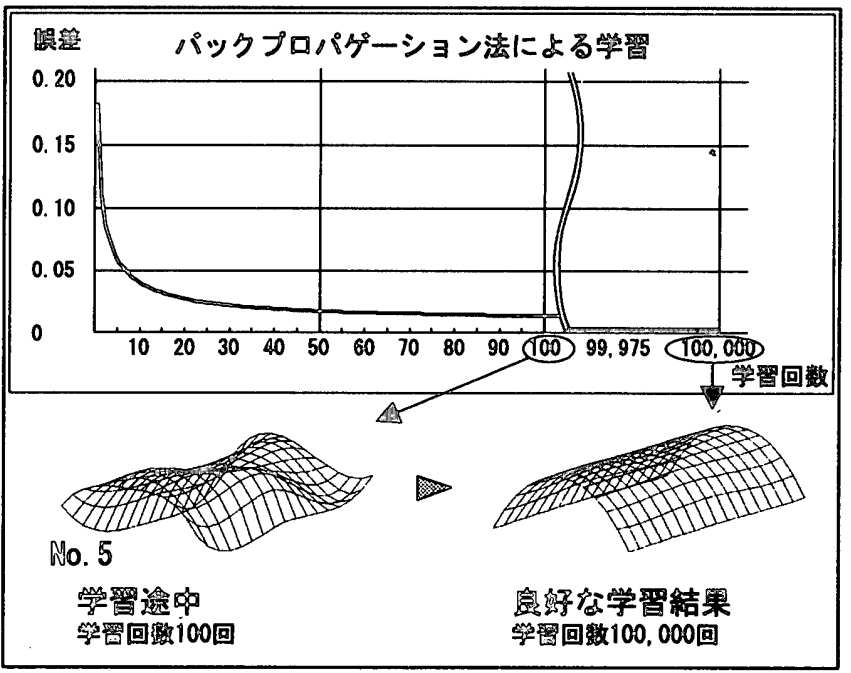

図 5 ニューラルネットワークモデルの学習結果 
えたが，逆に，「より安定的でなく」という修正も考えられるが，そ の場合には, 修正操作は,

$$
\mathbf{x}^{\prime}=\mathbf{x}-\delta \mathbf{a}_{i}
$$

と表現することができる。さらに，いちど修正したものを，別の形 "容詞 $\mathbf{W}_{i^{\prime}}$ で「さらに $\mathbf{W}_{i}$ に」という修正は,

$$
\mathbf{x}^{\prime \prime}=\mathbf{x}^{\prime}+\delta_{i^{\prime}} \mathbf{a}_{i^{\prime}}=\mathbf{x}+\delta \mathbf{a}_{i}+\delta_{i^{\prime}} \mathbf{a}_{i^{\prime}} .
$$

という操作として表現できる。図6に（実際には $\mathrm{K}$ 次元空間である が） 2 次元で上記のベクトル操作を概念的に示した。

上記の操作は連想イメージ空間の位置の変化であるが, 幾何学的 な形状そのものは, デザイン変数によって決まるので, 連想イメー ジ空間での修正結果 $\mathbf{x}^{\prime}$ から，これに対応するデザイン変数 $\mathbf{y}^{\prime}$ を求め る必要がある。これは, 前述の連想イメージ空間からデザイン変数 空間への写像 $\phi$ を用いて,

$$
\mathbf{y}^{\prime}=\phi\left(\mathbf{x}^{\prime}\right)
$$

として求めればよい。

\section{7-2 操作例}

「より安定に」という言葉を入力したときの形状出力結果および， さらに「より安定に」を絽り返したときの形状出力結果を図 7 左に 示す。図 7 右は「より軽快に」を 1 回および 2 回絽り返したときの 形状出力結果を示した。この例のように，言葉を与えるだけで，形 状が修正できることが確認できた。ディスプレイ画面を見ながら上 記の形容詞のみによる操作を繰り返すだけで, 自分の意図した形状 に修正してゅくことが可能であり，さらに，操作実験中に，言葉を 操るだけで, 当初考えてもいなかった形状のものを見いだすことも あった。

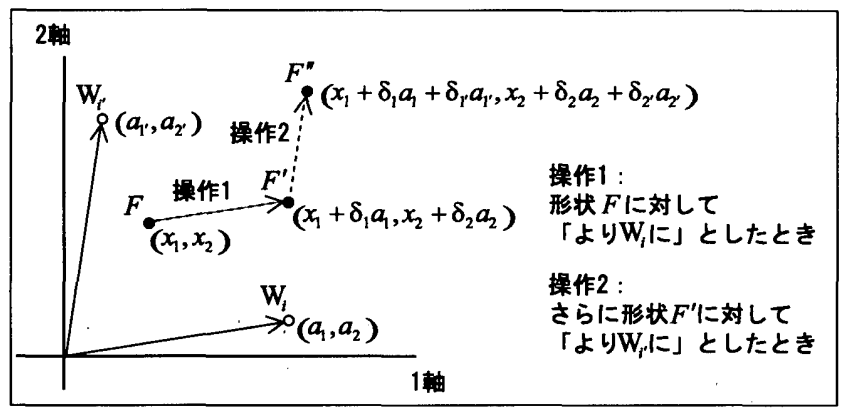

図 6 言葉による修正と連想イメージ空間上での移動

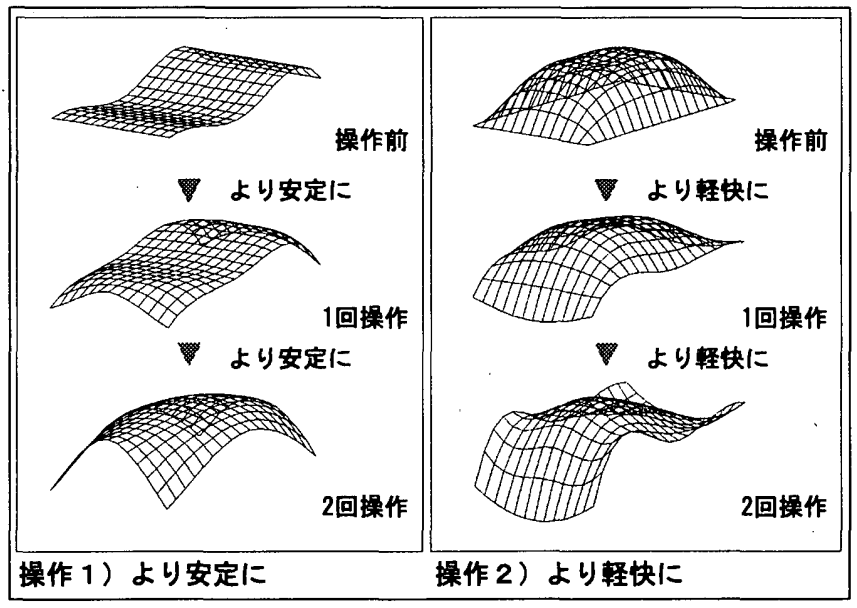

図 7 言葉を入力したときの形状出力結果

\section{8 考察とまとめ}

本報告では，言語表現によって設計案を修正するという状況を再 現するモデルを構築し，その操作実験を繰り返した。

まず,このようなモデルの構築によって，設計支援システムをよ り使い易いものとする可能性があるという点が指摘できる。

次に，この研究を通じて，以下のように言語の役割をわずかでは あるが明らかにすることが出来たことを指摘できる。モデルの機構 の主要な部分は, 形状と言葉を関連づける連想イメージ空間である。 この形状と言葉とを関係づけるモデルとしては，これ以外のモデル の可能性はあるものの, 形状の意味と言葉の意味が同一の空間で表 現されることが可能でなければ，上記のような修正操作は困難であ る。この点を考虑すると, 実際の設計においても建築家とスタッフ の間には共有した形状と言葉を結びつける機構が成立していなけれ ばならない。このことは, 設計時点よりも以前に,このような機構 が建築家とスタッフの間で形成されていることを意味し, 常日頃か らの形状についての言語的コミュニ゙ケーションが重要であることを 物語っている。

注

1）本項の連想イメージ空間の構成法は文献10)で異なる目的のために提案さ れたもので, 数理的展開については同文献を参照。

2）見る視点からの印象の違いを避けるため，被験者が梘点を自由に選べる ディスプレイ画面で提示した。

3）実際の設計チームで活用するときは，チームメンバーを被験者とする必要 がある。連想イメージ空間の各ベクトルの布置は異なってくるが活用方法 は以下と同様に可能である。

4）ニューラルネットワークモデルについては，たとえば文献11）文献12）参 照。

5）修正操作は連想イメージ空間内の位置の変更であって，連想イメージ杂間 の推定に伴う誤差の問題とは別次元の問題である。

文献

1) 渡辺俊一: プランの检証に関する若干の考察, 都市計画, No. 60, pp. 167$172,1969.11$

2) 渡辺俊一: ブランの「正しさ」の検証方法に関する若干の考察, 日本都市 計画学会学術講演論文集 (都市計画別冊), No. 5, pp. 132-139, 1970.11

3）青木義次: 計画行為の妥当性に関する論証, 日本建築学会計画系論文集, 第 527 号, pp. 143-148, 2000.1

4) 藤井晴行 - 青木義次: 計画行為の妥当性論証にむけた公理化, 日本建筑学 会計画系論文集，第 532 号, pp.157-162,2000.6

5）青木義次：計画言語論, 東京工業大学修士論文「計画過程に関する基䃈的 研究第 I 編」, 1972.3

6）青木義次: 計画の構造と手法, 建築研究所研究報告, №.80, 1977.7

7）藤井晴行・勝倉裕·中井正一: 行動を計面し実践する行為主体の形式表現, 日本建築学会計画系論文集，第 482 号, pp. 249-258, 1996.4

8) 藤井晴行 - 中井正一: 多種の教義が関与する設計過程の巨梘的構造, 日本 建築学会計画系諭文集, 第 518 号, pp.335-340, 1999.4

9）青氺義次: 経験的知識活用のための状況アスペクト推論法の提案, 日本建 築学会計画系論文集，第535 号, pp. 155-162,2000.9

10）青木義次 ·大佛俊泰・佐々木斎・広木晃·菅野元衛：連想イメージ区間の 構成論, 日本建築学会大会学術講演梗概集, pp.745-746, 1989.9

11) 臼井, 岩田, 久間, 浅川編 : 基碟と実践ニューラルネットワーク,コロナ 社, 1995

12）日本建築学会編: 知的システムによる建築・都市の創造,技術堂出版, 1998 (2001年 3 月 21 日原稿受理， 2001 年 8 月 20 日採用決定) 